\begin{tabular}{|l|l|r|}
\hline $\begin{array}{l}\text { 2. To: (Receiving Organization) } \\
\text { Distribution }\end{array}$ & $\begin{array}{l}\text { 3. From: (Originating Organization) } \\
\text { Effluent Treatment and } \\
\text { Laboratory Projects }\end{array}$ & $\begin{array}{r}\text { 4. Related EDT No.: } \\
\text { N/A }\end{array}$ \\
\hline $\begin{array}{l}\text { 5. Proj-/Prog-/Dept./Div.: } \\
\text { Project W-087 }\end{array}$ & $\begin{array}{l}\text { 6. Design Authority/ Design Agent/cog. } \\
\text { Engr.:JJ Beyer, DS McShane }\end{array}$ & $\begin{array}{l}\text { 7. Purchase Order No.: } \\
\text { N/A }\end{array}$ \\
\hline
\end{tabular}

8. Originator Remarks:

W-087 Acceptance Test Report

9. Equip./Component No.:

$\mathrm{N} / \mathrm{A}$

10. System/Bldg./Facility:

219-S, 244-S, and 242-S

11. Receiver Remarks: 11A. Design Basel ine Document? [] Yes [X] No

None

12. Major Assm. Dwg. No.:

N/A

13. Permit/Permit Application No.: $N / A$

14. Required Response Date:

$N / A$

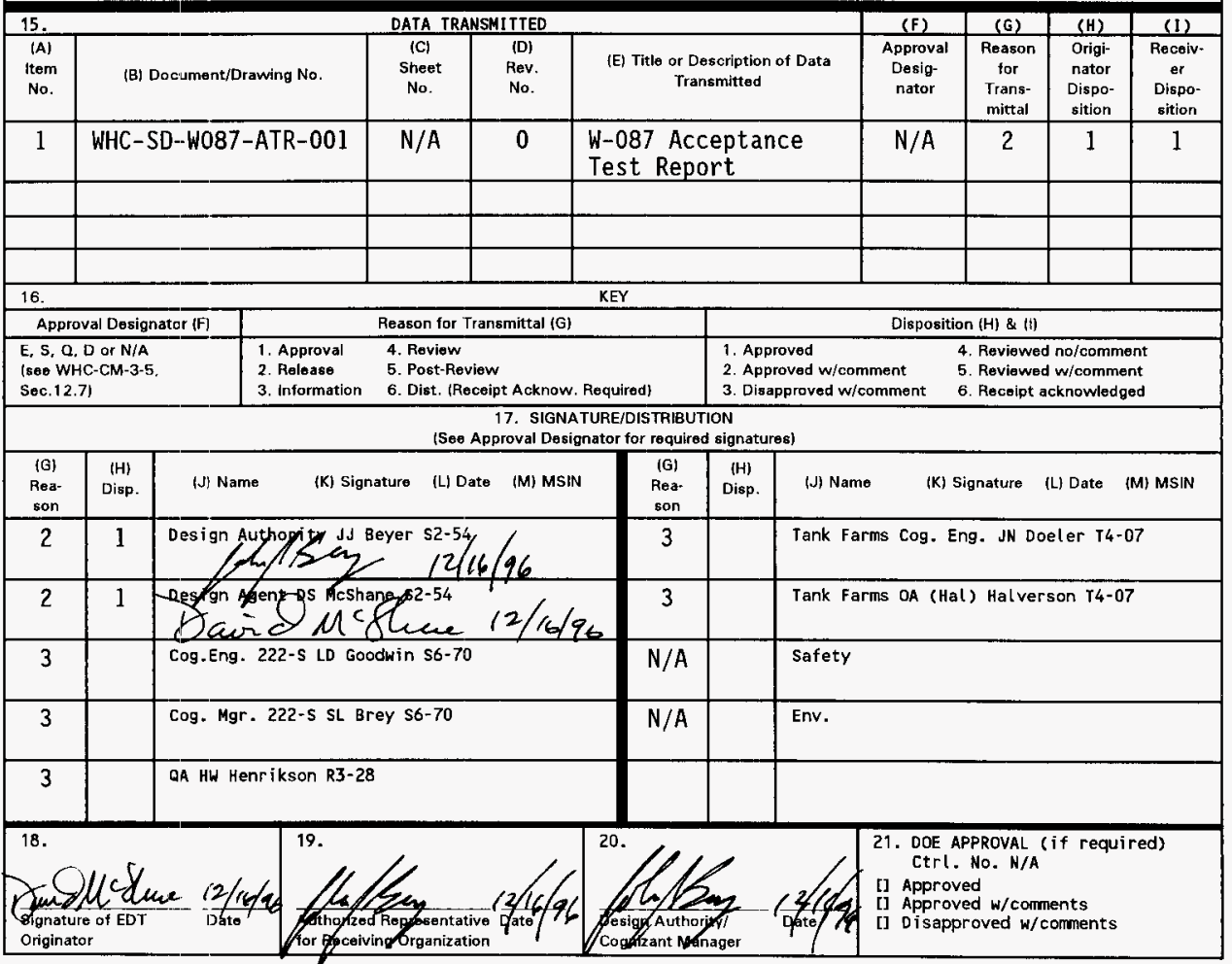

BD-7400-172-2(05/96) GEF097 


\title{
W-087 Acceptance Test Report
}

\author{
A. N. Joshi
}

Fluor Daniel Northwest, Richland, WA 99352

U.S. Department of Energy Contract DE-AC06-87RL10930

$\begin{array}{ll}\text { EDT/ECN: }=D T-607285 & \text { UC: } 2030 \\ \text { Org Code: 04E00 } & \text { Charge Code: YL4L1 } \\ \text { B\&R Code: EW3130030 } & \text { Total Pages: 26 }\end{array}$

Key Words: Acceptance Test Report for Project W-087 Underground Transfer Line from the 222-S Laborator to the S-Tank Farm.

Abstract: An Acceptance Test Report for the testing of Pumps, Leak Dectors, and Controls of an underground transfer line.

TRADEMARK DISCLAIMER. Reference herein to any specific comercial product, process, or service by trade name, trademark, manufacturer, or otherwise, does not necessarily constitute or imply its endorsement, recommendation, or favoring by the United States Government or any agency thereof or its contractors or subcontractors.

Printed in the United States of America. To obtain copies of this document, contact: WHC/BCS Document Control Services, P.0. Box 1970, Mailstop H6-08, Richland WA 99352, Phone (509) 372-2420; Fax (509) 376-4989.
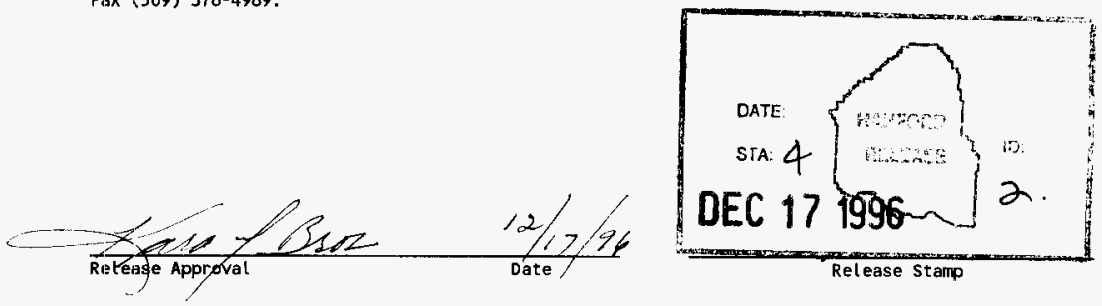

\section{Approved for Public Release}


ACCEPTANCE TEST PROCEDURE HHC-SD-W087-ATR/OFP-001

TEST TITLE Radioactlye Haste Transfer Line Equipment. Leak Detection System, and

Transfer Pump

LOCATION 219-5, 242-S, 244-5, 222-5 ROOM 3B

PROJECT NUMEER W-087 HORK ORDER

PROJECT TITLE Radioactive Waste Transfer Line Replacement

Prepared By

ICF Kaiser Hanford Company

Richland, Washington

For Westinghouse Hanford Company

Subcontract WHC 380393

PROCEDURE APPROVAL

ICF KAISER HANFORD COMPANY (ICF KH)

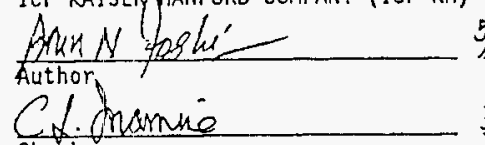

Checker

$\frac{5 / 10196}{\text { Date }}$

$\frac{\text { Rolest B } 21 \text { poram }}{\text { Technical Dodunts }}$

$\frac{5-10-96}{\text { Date }}$

$\frac{5 / 0 / 46}{\text { Date }}$

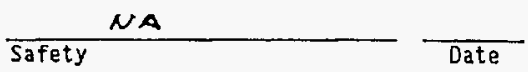

$\frac{N A}{\text { Environimental }}$

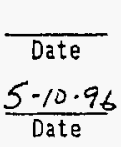

$\frac{\sim A}{\text { Quality Engineering }}$

Date

Westinghouse Hanford Company (WHC)

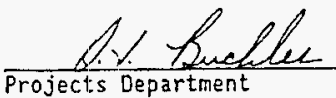

D. Thech

$\frac{A}{\text { Safety }} \frac{\text { SEE }}{6 D T} 615120$
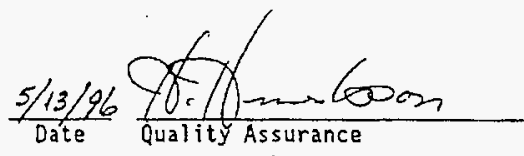

$\frac{5 / 13 / 96}{\text { Date }}$

$\frac{5 / 13 / 96}{\text { Date }}$

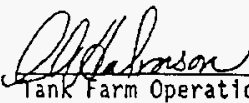

s. $10.9 L$

SEE EDT $615 \% 20$

Analytica) Services
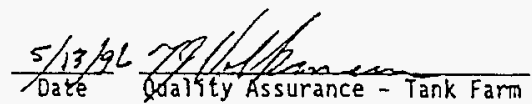

$\frac{5 / 13 / 96}{\text { Date }}$

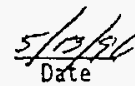

WHC-SD-W087-ATR-001

Rev. 0

$12 / 04 / 96$ 


\section{EXECUTED BY}

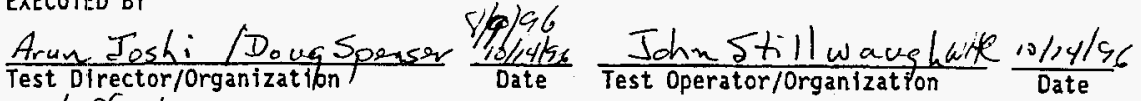
$\frac{\text { C/iff Lerstem } z c F \text { Kaiser }}{\text { Recorder/Organization }} \frac{1 / 1 / 96}{\text { Date }}$

\section{WITNESSES}

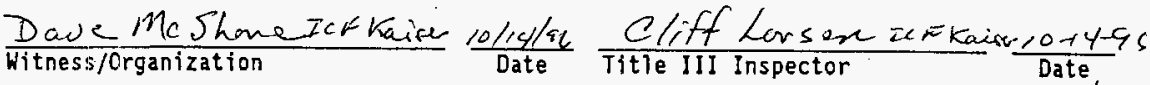

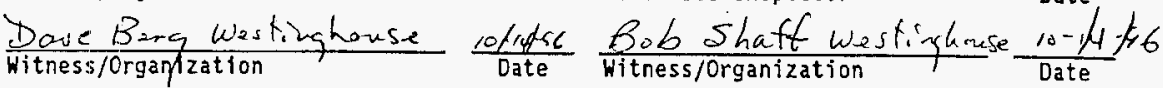

A-E APPROVAL

ICF Kaiser Hanford Company (ICF KH)

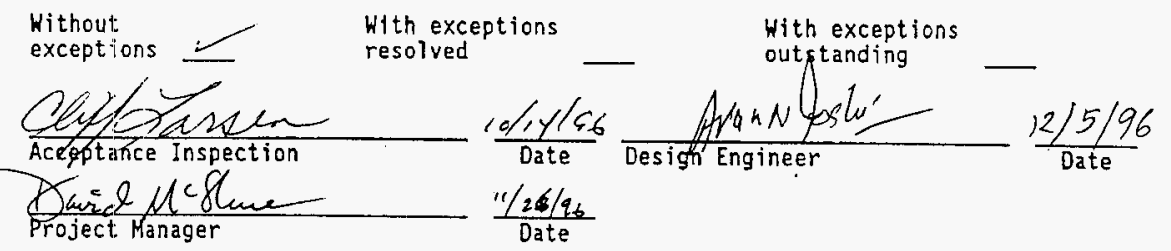

TEST APPROVAL AND ACCEPTANCE

Westinghouse Hanford Company (WHC)
Without. exceptions

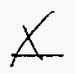
With exceptions
With exceptions resolved outstanding

$3 \times 10$

<Title or Department>
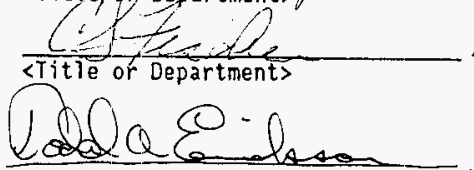

D. OT.5 MGR + SkIRTMGR
WHC-SD-W087-ATR-001

Rev. 0

$12 / 04 / 96$ 
TITLE/PROCEDURE APPROVAL

\section{TABLE OF CONTENTS}

$$
\text { PURPOSE }
$$

4 CHANGE CONTROL 9

5 EXECUTION 9

6 EXCEPTIONS IC

7 PREREQUISITES, EQUIPMENT/INSTRUMENTS, COHPONENT LOCATIONS, ANE ABBREVIATIONS 11

8 LEAK DETECTION AND MONITORING SYSTEM

9 TRANSFER PUMP PI SPEED CONTROL 16

10 MOTOR OPERATED VALVES HV-P1 AND HV-305 19

11 INTEGRATED SYSTEM (DRY) TEST AND INTERLOCK VERIFICATION 22

EXCEPTION FORM

NOTE: At completion of test, enter pages added during performance of test. to this Table of Contents. 
This Acceptance Test Procedure/Operational Test Procedure (ATP/OTP) has been prepared to demonstrate that the Electrical/Instrumentation and Mechanical systems function as required by project criteria and to verify proper operation of the integrated system including the interlocks.

The equipment to be tested includes the following:
a. Leak detection system operation and controls.
b. Electrical interlocks.
c. Transfer pump operation.
d. Vacuum breaker system interlocks.

The following tests will ensure the operation of the equipment used in support of radioactive liquid transfer from 222-5 Laboratory Facllity to 219-5, 242-5, and then to $244-5$. This test will include checks on associated annunciator systems.

The leak detection system uses 3 leak detector elements (LDEs) to monitor the entire length of pipe installed between 219-5 and 244-5.
a. LDE-306A monitors approximately 925 feet of pipe between 219-S and LDE-306A.
b. LDE-3068 monitors approximately 1000 feet of pipe between LDE-306A and LDE-3068.
c. LDE 306C monitors approximately 1005 feet of pipe between LDE-306B and LDE-306C.

The leak detectors are connected to leak detection panels mounted locally. The signals are transmitted to control panels located at $219-5,242-5$ and $244-5$. Leak detection annunciation is provided at $219-5,222-5$ Room $3 B, 242-5$ and 244-S; and has capability to connect to Central Alarm Surveillance System (CASS).

The leak detection signals are connected to the transfer pump interlock. The pump interlocks are arranged such that evidence of leak in any section of the pipe, or a pump diaphragm leak, or a manual override by the DENY pushbutton will stop pump operation.

The transfer pump is air operated diaphragn type, operated by pneumatic controller. Air supply to the pump is controlled by an in line motor operated valve. If leak detection system is activated, the pump interlock circuit will prevent pump operation. In addition, if pump diaphragm should leak, pump interlock circuit will prevent pump operation. 


\subsection{DRAWINGS}

\subsubsection{Froject W-087 Drawings}

H-2-820841, Sh 1 and 2, Rev 0 H-2-820842, Sh 1, Rev. O H-2-820843, Sh 1, Rev. 0 H-2-820848 Sh 1, Rev 0
Instrumentation Conn. Diagrams

242-S Panel A Modifications 242-S Pane] A Interconn. Diagram Leak Detection, Elem. Diagram

2.1.2 Froject $W-178$ Drawings Showing Interface with Project $\mathbf{W - 0 8 7}$

H-2-825536, Sh 1, Rev. 0

H-2-825549 Sh 1, Rev 0

Cell A \& Operating Gallery

$\mathrm{H}-2-825550 \mathrm{Sh}$ 1, Rev 0 Leak Detection Panel IP2

Control Panel IP3

\subsection{SPECIFICATIONS}
H-OB7-C1, Rev 0
H-OB7-C2, Rev 0
Construction Specification
Construction Specification

2.3 VENDOR INFORMATION
a. Leak detection system (B/W Magnatek): VI 22687, Supplement No. 8.
b. Diaphragm pump and diaphragm leak detection and speed control unit (Sandpiper): VI 22687, Supplement No. 1.
c. Motor operated valve (MOV) actuator (Worcester): VI 22687, Supplement No. 9.

2.4 OTHER
a. Tank Farm Operating Procedure T0-410-950 (Draft).
b. Safety Hanua 1, WHC-CM-1-10.
c. Butlding Emergency Plan, WHC-1P-0263-TF.
d. Industrial Hygiene Manual, WHC-CM-1-11.
e. Tank Farm Health and Safety Plan (HASP), WHC-SD-WM-HSP-002.
f. Hanford Site Radlological Control Hanual (HSRCM).
g. Environmental Compliance Manual, WHC-CM-7-5.
h. Standard Engineering Practices, WHC-CM-6-1, EP-2.2.

2.5 ENGINEERING CHANGE NOTICES (ECNS)
ECN $\mathrm{W}-087-12$
ECN $\mathrm{H}-087-23$
ECN $\mathrm{H}-087-26$
ECN $\mathrm{H}-087-46$
ECN $W-087-50$
$E C N-W .087-41$
$6 \frac{3}{5}$
66

WHC-SD-W087-ATR-001

Rev. 0

$12 / 04 / 96$ 
ELN K-087-54

Prior to final test approval, enter ECNs written against this ATP/OTD.

3 RIESPONSIBILITIES

3.1 GENERAL

Each company or organization participating in this ATP will designate personnel $t_{1}$ assume the responsibilities and duties as defined herein for their respective roles. The designees shall become familiar with this ATP and the systems involved to the extent that they can perform their assigned duties.

3.2 WHC PROJECT ENGINEER

3.2.1 Designates a Test Director.

3.2.2 Distributes the approved testing schedule before start of testing.

3.2.3 Schedules and conducts a pretest kickoff meeting with test participants when necessary.

3.2.4 Schedules prejob safety meetings.

3.2.5 Schedules a dry run when necessary.

3.2.6 Notifies concerned parties when a change is made in the testing schedule.

3.2.7 Notifies the persons supporting the test 2 days before the start of testing.

3.2.8 Coordinates testing with the 219-5, 222-S, 242-S, 244-S, 200-West Area, Tank Farm Managers, Tank Farm Operations Cognizant Engineer, and Shift Hanager.

3.2.9 Acts as liaison between the participants in acceptance testing.

3.2.10 Signs Execution and Test Approval page when test is approved and accepted.

3.2.11 Takes necessary action to clear exceptions to the test.

3.2.12 Signs Exception Form when exception has been resolved.

3.2.13 Provides a distribution list for the approved and accepted ATP(ATR).

\subsection{TEST DIRECTOR}

3.3.1 Coordinates and directs acceptance testing.

3.3.2 Confirms that field testing and inspection of the system or portion of the system to be tested has been completed. 
3.3.3 Stops any test which, in his or her judgment, may cause damage to the systern until the problem has been resolved.

3.3.4 After verifying there is no adverse impact, may alter the sequence in which systems or subsystems are tested.

3.3.5 Ensures that required environmental conditions are maintainec.

3.3.6 If a test is to be suspended for a period of time, ensures that tive system is left in a safe mode.

3.3.7 Before restarting suspended test, reverifies the test prerequisites.

3.3.8 Inftiates ECNs to document required changes to the ATD.

3.3.9 Reviews recorded data, discrepancies, and exceptions.

3.3.10 Obtains information or changes necessary to clear or resolve objections during the performance of the test.

3.3.11 Signs Execution and Test Approval page when test has been performed,

3.3.12 Signs Exception Form when exception has been resolvec.

3.3.13 Obtains required signatures on the ATP Master prior to reproduction and distribution.

3.4 WITNESSES (Provided by Participating Organizations. One witness shall be a Title III acceptance inspector.)

3.4.1 Witness the tests.

3.4.2 Review results of testing.

3.4.3 Assist the Test Director when reouested.

3.4.4 Sign Execution and Test Approval page when test has been performed.

3.4.5 Sign Exception Form when exception has been resolvec.

3.5 RECORDER (Provided by ICF KH)

3.5.1 Prepares a Field copy from the ATP Master.

3.5.2 Records printed names, titles, and initials of all designated personnel on Field copy of ATP prior to start of testing.

3.5.3 Records test instrument Identification numbers and calibration expiration dates, as required.

3.5.4 Initials and dates every test step on the field copy as it is completed next to the step number or on a data sheet, when provided. Records test data. On data sheets where there is not room for botr. the initial and date, date may be entered at bottom of column. 
3.5.5 Records objections and exceptions on an Exception form. Uses additional Exception forms as needed. Notifies the Test Director at time the objection is made.

3.5.6 Signs Execution and Test Approval page when test has been performed.

3.5.7 After test is finished, assigns alpha numeric page numbers to added data sheets and Exceotion forms. Records page numbers in the Table of Contents.

3.5.8 Transfers Field copy entries for each step to the Master in ini or type, signs, and dates. Transmits the completed Master to the Tes: Director for approval signature routing. Transmits the Field copy to Construction Document Control for inclusion in the official proje: file.

3.5.9 Signs Exception Form when exception has been resolved and transmits to Test Director.

\subsection{TEST OPERATOR}

3.6.1 Performs test under direction of the Test Director.

3.6.2 Provides labor, equipment, and test instruments required for performing tests which have not been designated as being provided by others.

3.6.3 Requests in writing from the Test Director those services, materials, or equipment that have been designated as being supplied by others.

3.6.4 Confirms that all equipment required for performing test will be available at the start of testing.

3.5.5 Signs the Execution and Test Approval page.

3.7 A-E ACCEPTANCE INSPECTION, DESIGN ENGINEER, AND PROJECT MANAGER

3.7.1 Evaluate resulis.

3.7.2 Sign for A-E Approval on Execution and Test Approval page.

3.8 TANK FARM SHIFT OPERATIONS MANAGED

3.8.1 Designates an oDerator to witness and/or complete the ATP/OTP for Tank Farms.

3.8.2 Assumes responsibility for the safe conduct of the ATP/OTP within Tank Farms.

3.8.3 Authorizes the start of the ATP/OTP for Tank Farms.

3.8.4 Signs Execution and Test Approval page when test is approved and acceptes.

3.8.5 Signs exception form, when exception has been resolved. 
3.9 TANK FARM OPERATOR

3.9.1 Witnesses the test for Tank Farms.

3.9.2 Operates equipment as designated by the Test Director:

3.9.3 Signs Execution and Test Approval page when test has been completed.

3.9.4 Signs Exception Form when exception has been resolved.

3.10 TANK FARH COGNIZANT ENGINEER

3.10.1 Approves modifications to the ATP/OTP.

3.10.2 Signs Execution and Test Approval page when test has been completed.

3.10.3 Signs Exception Form when exception has been resolved.

3.10.4 Reviews recorded data, discrepancies, and exceptions.

4 CHANGE CONTROL

Required changes to this ATP must be processed on ECNs in accordance with company procedures. If a need for change is discovered in the course of running the test, the test director shall review the change(s) required to the procedure and discuss with the design engineer or representative. If the changes required do not affect the configuration, the changes shail be redined and signed by the design engineer and the test director for incorporation into an ECN. During this resolution, other portions of the test, unaffected by the change, may proceed.

5 EXECUTION

5.1 OCCUPATIONAL SAFETY AND HEALTH

Individuals shall carry out their assigned work in a safe manner to protect themselves and others from undue hazards and to prevent damage to property and environment. Facflity line managers shall assure the safety of activities within their areas to prevent injury, property damage, or interruption of operation. Performance of test activities shall always include safety and health aspects.

\subsection{PERFORMANCE}

5.2.1 Conduct testing in accordance with ICF KH Procedure CON 3.5 (Performance and Recording of Acceptance Test Procedures).

5.2.2 Perform test following the steps and requirements of this procedure. 
6.1 GENERAL

Exceptions to the required test results are sequentially numbered and recorded on individual Exception forms. This enables case-by-case resolution and approval of each exception.

Errors/exceptions in the ATP itself shall NOT be processed as test exceptions (see Section 4 CHANGE CONTROL).

\subsection{RECORDING}

6.2.I Number each exception sequentially as it occurs and record it on an Exception Form (KEH-428), sample appended.

6.2.2 Enter name and organization of objecting party for each exception.

6.2.3 Enter planned action to resolve each exception when such determination is made.

\subsection{RETEST/RESOLUTION}

Record the action taken to resolve each exception. Action taken may not be the same as planned action.

6.3.1 Wen action taken results in an acceptable retest, sign and date
Retest Execution and Acceptance section of the Exception Form.

6.3.2 When action taken does not involve an acceptable retest, strike out the Retest Execution and Acceptance section of the Exception Form.

6.4 APPROVAL AND ACCEPTANCE

The customer provides final approval and acceptance of exceptions by checking one of the following on Exception Form:

6.4.1 Retest Approved and Accepted: Applicable when Retest Execution and Acceptance section is completed.

6.4.2 Exception Accepted-As-Is: Requires detalled explanation.

6.4.3 Other: Requires detailed explanation.

The customer signs and dates the Exception form and obtains other customer internal approvals, if required.

6.5 DISTRIBUTION

A copy of the approved Exception Form is distributed to each participant. The signed original is attached to the ATP Master. 


\subsection{PREREQUISITES}

The following conditions shall exist at start of testing for that portion of the system being tested.

\subsubsection{Systems have been inspected for compliance with construction} documents.

7.1.2 Vendor data and operating Instructions are at hand for each installed instrument, pump, and valve.

7.1.3 Reference documents (including this ATP) have been verified for correct reviston number and outstanding ECNs.

7.1.4 A Job Safety Analysls has been prepared by ICF KH and a Prejob Safety Meeting has been conducted.

7.1.5 Test instruments have a valid calibration stamp attached. Test instrument identification numbers and calibration expiration dates have been recorded in Para 7.2 .

7.1.6 Methods of water disposal have been approved by Facilities Management.

7.1.7 Power is available to energize the system: Cir.at -24 at 445, Cireu if \#3

7.1.8 Annunciator lights have been tested.

7.1.9 Voice communications are available between 219-5, 222-5, 242-5, 244-S, leak detection sensor locations, and other locations determined to be approprlate by the test director.

7.1.10 Radiation Work Permits (RWPS) have been approved by the Operating Contractor. Attach RWPS to ATP.

7.1.11 Pump Pl spool piece is disconnected from Tank 102.

7.1.12 Project equipment and instruments have been identified by tag numbers.

7.2.13 Shop test results for Panels IP1, IP2, and IP3 are on file, for record, with ATP/OTP.

\subsection{EQQUIPMENT/INSTRUMENTS}

Supplied by Test Operator unless otherwise noted.

$7.2 .1 \quad$ Voltohmmeters $(\mathrm{VOM})$ :
$950-45-08-018$

Instrument No. $\frac{0054}{950-45-08-015}$ Expiration Date $\frac{3-14-97}{2-26-57}$

Znz-Z Swtthable Shorting Jumpers? Length, I foot through-6 foot-as

required. ECN-GF 
7.2.3 Pressure Gages: $\quad 0-100$ psig. Pressure test assembly used for tank trallers may be used for this ATP.

7.2.4 Contafner: To hold water for leak detector tests, approximately 1 gallon capacity.

\subsubsection{Tubing: 1/4-inch and 1/2-inch tygon.}

\subsection{COMPONENT LOCATION}

\begin{tabular}{|l|c|}
\hline \multicolumn{1}{|c|}{ Component Identifier } & \multicolumn{1}{|c|}{ Location } \\
\hline Control Panel IP2 & $219-5$ \\
\hline Control Panel IP3 & $219-5$ \\
\hline $\begin{array}{l}\text { Hotor Operated Valves HV-P1 } \\
\text { and HV-305 }\end{array}$ & $219-5$ \\
\hline Panelboard (219-SX) & \multicolumn{1}{|c|}{$219-5$} \\
\hline $\begin{array}{l}\text { Leak Detector Elements LDE-306A, } \\
306 B, 306 C\end{array}$ & $\begin{array}{l}\text { On the transfer piping between } \\
\text { Tank-102 and 244-S }\end{array}$ \\
\hline $\begin{array}{l}\text { Leak Detector Transmitters LDT-306A, } \\
306 B, 306 C\end{array}$ & $\begin{array}{l}\text { Outside, between 219-S and } \\
244-S\end{array}$ \\
\hline \begin{tabular}{l} 
Pusshbuttons PERMIT and DENY \\
\hline
\end{tabular}
\end{tabular}

7.4 ABBREVIATIONS

CASS Central ATarm Surveillance Systems

ECN Engineering Change Notice

LDE Leak Detector Element

LDT Leak Detector Transmitter

LOY Leak Detection Relay

HoV Motor-Operated Valve

RWP Radiation Nork Permit 
This test will verify operation of the leak detection system consisting of LDE, leak detection processor, annunciation and control interlock. This system is based upon conductivity principle. When the liquid due to leak contacts both the ground probe and the leak detection probe of the LDE, leak detection relays deenergize and provide annunciation, local indication by beacon light, and interlock outputs.

8.1 PREPARATION

ckiov4t56

Verify all prerequisites of Para 7.1 and 7.2 have been met.

Verify that energized electrical work permits have been obtained.

HOTE: Keep appropriate personnel informed as to test status.

CAITTIOH: TEST INYOLVES WORKING HITH LIVE CIRCUITS. ENSURE THAT THE IMMEDIATE AREA IS NOT WET. ENSURE THAT HANDS AND APPAREL ARE DRY.

8.2 LEAK DETECTION AND MONITORING SYSTEM TEST

Record the following steps for each LDE/LOT loop on Data Sheet 8.2.

8.2.1 Remove LDE from pipe.

8.2.2 Apply power to monitoring units (Circuit 24, Panelboard $B$ at 244-S, Circuit 3 at Panelboard 242-5, and Circuit 27 at 219-5).

B.2.3 Immerse LDE in liquid. $5,7,8^{2}$ ecollo

8.2.4 Verify white indicating beacon light at $244-5$ is $O N$.

8.2.5 Verify contact 1-7 of LDT in Panel IP2 at 219-5 is CLOSED.

B.2.6 Verify Annunciator Window 1-1, ENCASEMENT LEAK on Panel A at 242-5 is FLASHING and audible alarm is ON.

B.2.7 Verify Annunciator Hindow 3-5, TRANSFER LINES TO 244-S on Panel IP3 at $219-5$ is FAST FLASH and audible alarm is ON.

8.2.8 Verify Group Annunciator A1-38, Window 9, DRAIN LEAK DETECTION at 222-S Room $3 B$ is FLASHING and audible alam is ON.

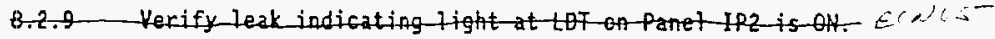

8.2.10 Verify leak indicating light at Panel IP3 is ON.

8.2.11 Depress ACKNOWLEDGE pushbutton at 219-S and verify Annunciator Window 3-5 is STEADY ON and audible alarm is OFF. 
8.2.12 Depress ACKNOWLEDGE pushbutton at 242-S and verify Annunciator Window $1-I$ is STEADY $O N$ and audible alarm is OFF.

8.2.13 Depress ACKNOWLEDGE pushbutton at 222-S, Room $3 B$ and verify Annunciator Hindow $g$ is STEADY ON and audible alarm is OFF.

8.2.14 Remove LDE from liquid and dry it off.

8.2.15 Verify white indicating beacon light at 244-S is OFF.

8.2.16 Verify leak indicating light at LDT on Panel IP2 is OFF.

8.2.17 Verify Annunciator Window 3-5 at Panel IP3 is SLOW FLASH and audible alarm is $O N$.

8.2.18 Depress RESET pushibutton at Panel IP3 and verify Annunciator Hindow 3-5 and audible alarm are OFF.

8.2.19 Verify Group Annunciator $A 1-3 B$ Window 9 at $222-5$ Room $3 B$ is OFF.

8.2.20 Verify Annunciator Window 1-1 at 242-S is OFF.

8.2.21 Reinstall LDE in pipe. 


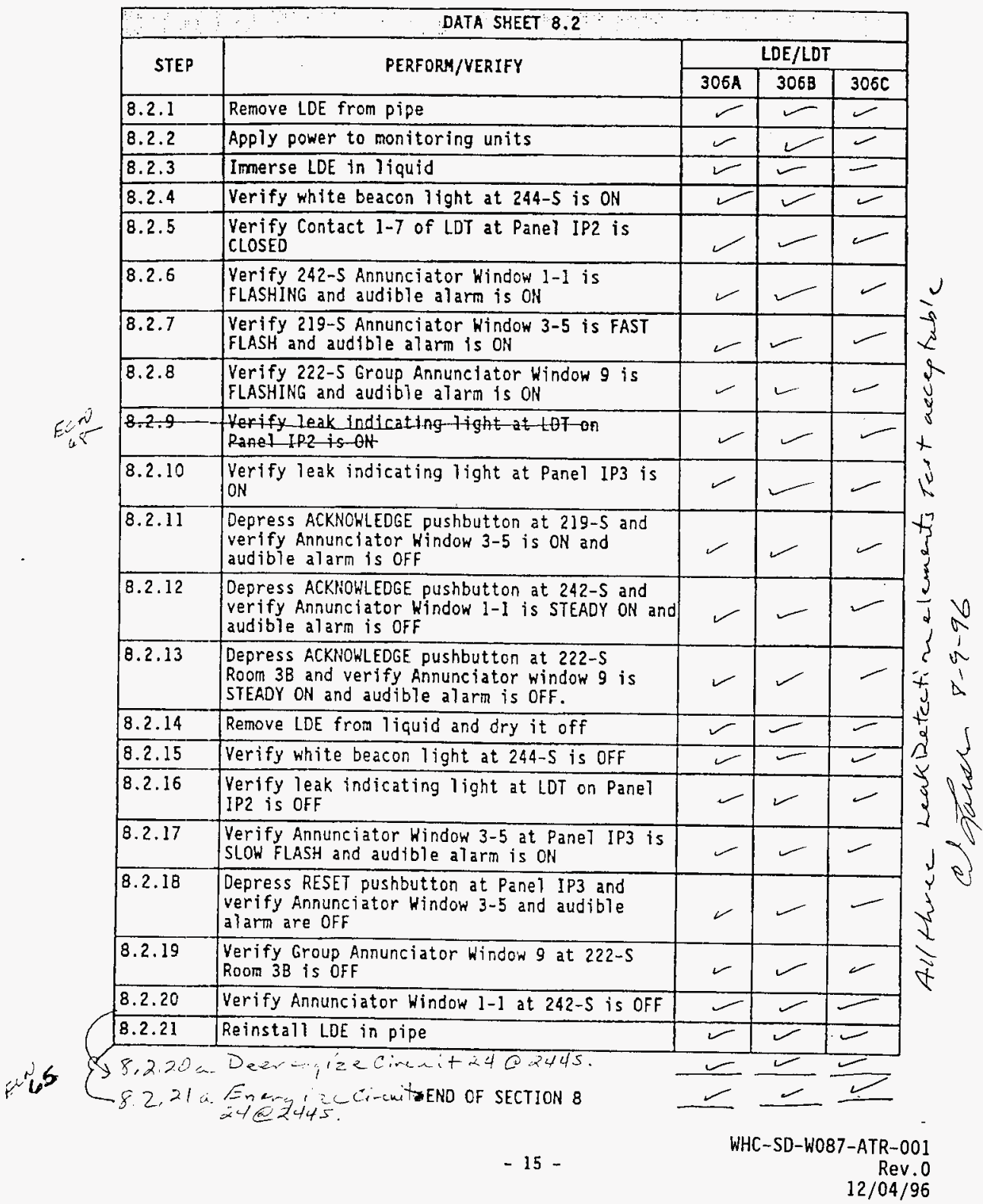


This test will verffy speed control operation of Pump P-1 in 219-5.

9.1 PREPARATION

Cheoyt 9.1 .1 Verify all prerequisites of Para 7.1 and 7.2 have been met.

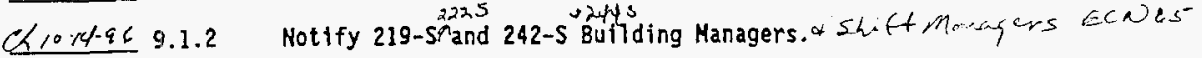

Ch10.496 9.1.3 Notify Tank Farms Operations and Shift Hanager.

Ch 10-14 56 9.1.4 Verify that energized electrical work permits have been obtained.

NOTE: Keep appropriate personnel informed as to test status.

CAUTION: TEST INYOLVES WORKING MITH LIYE CIRCUITS. ENSURE THAT THE IMMEOIATE AREA IS NOT HET. ENSURE THAT HANDS AND APPAREL ARE DRY.

9.2 TRANSFER PUHP P1 SPEED CONTROL TEST CW 5

CS lo ref-द 9.2.1 Verify Air Valve CA-V-6608 is CLOSED.

Ch, U-4.9: 9.2.2 Energize Circuit 3 for Panel A from Panelbaard C at 242-S.

Ch wow. 96 9.2.3 Energize Panels IP2 and IP3 at 219-S.

Cho-fere 9.2.4 Pull to reset DENY switch.

Choofess 9.2.5 Press and release PERMIT pushbutton.

Ch10.14-56 9.2.6 Verify TRANSFER PUMP P-1 indicating light on 242-S is on.

Chio-1496 9.2.7 Rotate pump speed control knob to o\% position.

CAUTION: High pressure air may be present. Perform following operation. slowly.

Cheo14-5/9.2.8 Disconnect instrument air tubing at the outlet of Regulator HY301.

Chroff-26 9.2.9. Install a tee fitting between the regulator outlet and the process tubing. Connect an instrument pressure gauge to the remaining end of the tee fitting.

NOTE: Readings taken from this pressure gauge, and recorded in this ATP/OTP, are for information only and have no bearing on the acceptance of this test.

Ch1014-969.2.10 Verify Valve HV-305 OPEN (red) indicating light on Panel IP3 is ON and VaTve HV-PI CLOSEO (green) tndicating light on Panel IP3 is ON.

Chro-4t-6 9.2.11 Verify pump speed control knob is turned to 0\% position.

Ch1014.96 9.2.12 Apply power to the electropneumatic controller (Circujt 8 at 219-SX). Ch.0.14.TS9.2.13 Open Air Vatve CA-V-650\%. 
CL,D-14! 9.2.14 Record reading on the pressure gauge. psi

Cho-rfsS 9.2.15 Turn Hand switch HS-305 to CLOSE position and hold whi e verifying the following.

Ch 10 +469.2 .15 .1 As the valve travels toward the closed position, verify both OPEN (red) and CLOSED (green) indicating lights are ON.

Ch 10 ret-9 9.2.15.2 When the valve reaches the fully closed position, verify OPEN indicating light is OFF and CLOSED indicating light is ON.

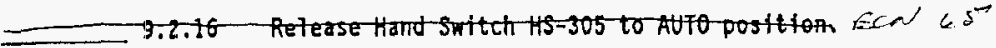

Ch 10-ryEC 9.2.17 Turn Hand Switch HS-P1 to OPEN position and hold while verifying the following.

Chroy4fG 3.2 .17 .1 As the valve travels toward the open position, verify both OPEN (red) and CLOSED (green) indicating lights are $O N$.

Chroy 4969.2 .17 .2 When the valve reaches the fully open position, verify CLOSED indicating light is OFF and OPEN indicating light is $O N$.

Chro y4-959.2.18 Release Hand Switch HS-P1 to AUTO position.

Chio $x$ - 59.2 .19 5lowly rotate pump speed control knob clockwise to $50 \%$ position.

Chio-kt-96 9.2.20 Record reading on the pressure gauge. 10 psi

NOTE: This reading should be higher than that taken with pump speed control knob at $0 \%$.

Chiotifes 9.2.21 Slowly rotate pump speed control knob to $100 \%$ position.

Cheo-14-969.2.22 Record reading on the pressure gauge. 22 psi

MOTE: This reading should be higher than that taken with pump speed control knob at 50\%.

C10.14969.2.23

Slowly rotate pump speed control knob back to $0 \%$ position.

Ch101446 9.2.24

Record reading on the pressure gauge. psi.

NOTE: This reading should be approximately the same as that taken when pump speed control knob was first at o\% position.

C410-14469.2.25

Turn Hand Switch HS-P1 to CLOSE position and verify the following.

Ch10-1.4569.2.25.1

As the valve travels toward the closed position, verify both OPEN and CLOSED indicating lights are $O N$.

Ch.o-14-\$6 9.2.25.2 When the valve reaches the fully closed position, verify CLOSED indicating $l$ ight is $O N$ and OPEN indicating light is OFF.

Cl10-14-969.2.25.3 Verify the closing of Vaive HV-Pl has caused Valve HV-305 to OPEN. ChroH-96 9.2.26 Close Air Vaive CA-V-5608̈.

WHC-SD-W087-ATR-001 
CAUTION: HIGH PRESSURE AIR RAY BE PRESENT. PERFORY FOLLONIHG OPERATION SLONLY.

- 9.2 .27 Reconnect the tubing to outiet sfo of Regutator HF301. ECW 6.5

Chro-34-5C 9.2.28 Remove power from Regulator HY301.

END OF SECTION 9

$-18-$

WHC-SD-W087-ATR-001

Rev. 0

$12 / 04 / 96$ 
These tests will verify that Motor Operated Valves HV-Pl and HV-305 operate in accordance with their respective elementary (contro1) diagram requirements.

HV-P1 is controlled by a 3 position (OPEN-AUTO-CLOSE) control switch which can be maintained in either AUTO or CLOSE position but will spring-return from OPEN to AUTO.

HV-305 is controlled by a 3 position (CLOSE-AUTO-OPEN) control switch which can be maintained in either AUTO or OPEN pOsition but will spring-return from CLOSE to AUTO.

Operation of HV-PI is dependent on the operation of HV-305. HV-P1 is designed as automatic CLOSE and manual override CLOSE while HV-305 is designed as automatic OPEN and manual override OPEN. In other words, HV-Pl will not OPEN unless HV-305 is CLOSED.

\subsection{PREPARATION}

Q. $10.14-48$

10.1.1 Verify all prerequisites of Para 7.1 and 7.2 have been met.

ch 10+4-96 10.1.2 Notify 219-S/and 242-S Building Managers.

Chro-14-EC 10.1.3 Notify Tank Farm Operations and Shift Manager.

Chioves 10.1.4 Verify that energized electrical work permits have been obtained.

NOTE: Keep appropriate personnel informed as to test status.

CAUTION: TEST INVOLVES WORKING WITH LIVE CIRCUITS. ENSURE THAT THE IMMEDIATE AREA IS NOT WET. ENSURE THAT HANDS AND APPAREL ARE DRY.

10.2 MOTOR OPERATED VALVE HV-PI AND HV-305 TEST

Chro-rf-4 10.2.1 Place Circuit Breaker 7 in Panelboard 219-5X, at Building 219-5, in the OFF position.

Cheor $14-9610.2 .2$ Verify there is NO VOLTAGE across Terminals TB2-205 and TB2-206 at Panel IP3.

Ch10-14-96 10.2.3 Place Circuit Breaker 7 in Panelboard 219-SX, at Building 219-S, in the on position.

Ch10wes 10.2.4 Place Circuit Breaker 27 in Panelboard 219-5, at Building 219-S, in the on position.

CL1.14 10.2 .5 Place Circuit No. 3 in Panelboard $C$, at Building 242-5, in the $0 N$ position.

Cher4-s 10.2.6 Verify DENY pushbutton in Panel A, at Building 242-S, is in PULL T0 RESET position.

Cho Press and release PERMIT pushbutton in Panel $A$ at Buirding 242-S.

Chiory.4C 10.2.8 Using VOM verify $120 \mathrm{~V}$ ac across Terminals TB2-201 and TB1-7N2. 
Ch 10-4t-5s 10.2.9 Verify PERMITTED indicating light on Panel IP3 is 0N.

ch $10-14-96$ 10.2.10

Verify TRANSFER PUMP $P-1$ indicating light on Panel $A$, in 242-S, is ON.

C 10-k9 10.2'.10a Turn and Hold selector switch for HV-305 to CLOSE. L4 See ECNS Ch1ere-gc 10.2.10b Verify that HV-305 is CLOSED. acalch

Chro-14-8s 10.2.10c Turn and Hold selector switch for HV-P1 to OPEN. Earuc Q10.ress 10.2.10d Verify that HV-P1 is OPENED. ECNul

Chrord-56 10.2.10e Release selector switch for HV-305 to AUTO. ECNu6 Chro $+4-9610.2 .10$ Release selector switch for HV-P1 to AUTO. Eunl 6

Cheor4-46 10.2.11 Turn selector switch for Valve HV-305 on Panel IP3 to OPEN.

Ch1. $14-95$ 10.2.12 Verify Valve HV-305 position handle at top of valve actuator

indicates OPEN and valve CLOSED (green) indicating light on Panel IP3 is OFF and valve OPEN (red) indicating light is ON.

Clo-r4ar 10.2. 12 Verify that HV-PI closes. ECr'b6

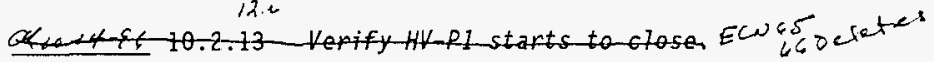

chror4-95 10.2 .14

eh, o-14-95 10.2 .15

$C_{h 10-14-S_{6}} 10.2 .16$

C40.19.96 10.2.17

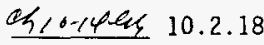

Chro-14as 10.2 .19

Ch1074-4s 10.2 .20

Ch10-14-9f 10.2.21

G, $0-14-9510.2 .22$

C.0.4-E, 10.2 .23

ch1014 10.2.24
Verify valve HV-PI position handle at top of valve actuator indicates CLOSE and valve CLOSED indicating light on Panel IP3 is ON.

Using VOM verify Relay K-V on Panel IP2 is ENERGIZED.

Turn selector switch for HV-PI from CLOSE to AUTO.

Verify Valve HV-Pl position handle at top of valve actuator continues to indicate CLOSE and valve CLOSED indicating light on Panel IP3 remains ON.

Turn and hold selector switch for HV-P1 in OPEN position.

As Valve HV-PI travels toward the open position, verify both OPEN and CLOSED indicating lights are $\mathrm{ON}$.

When Valve HV-P1 reaches the fully open position, verify CLOSED indicating light is OFF and OPEN indicating light is ON.

Release selector switch for HV-P1 to AUTO.

Verify Valve HV-Pl begins to close.

As Valve HV-P1 travels toward the closed position, verify both OPEN and CLOSED indicating lights are ON.

When Valve HV-Pl reaches the fully closed position, verify OPEN indicating light is OFF and CLOSED indicating light is ON. 
Ch 1044t6 10.2.25

chotyes 10.2 .26

Ch16-14-95 10.2 .27

Chistus 10.2.28

Ch10-14.45 10.2.29

CA10-14.96 10.2.30

$C h 10-14+4610.2 .31$

Chro-s4tis $10.2 .31 \mathrm{a}$

Ch10+1-96 10.2.32

ch10-1446 10.2.33

Chiottel6 10.2 .34

Ch coth96 10.2.35

chro-14.46 10.2.36

ehro-4-46 10.2.37

$0410 \cdot 14+610.2 .37 a$

Q100 1446 10.2.37b

ch 10y-4s 10.2 .38

Ch10-atal 10.2.39

C410+4.25 10.2 .40

Ch, o.14-95 10.2.41

c) $10-1-9610.2 .42$

C4.0-124.96 10.2.43

Q11. $1+4-510.2 .44$

Casuth\} 10.2.45

Turn and hold selector switch for HV-305 in CLOSE position.

As Valve HV-305 travels toward the closed position, verify both OPEN and CLOSED indicating lights are ON.

When valve position handle on Valve HV-305 shows fully closed, verify CLOSED indicating light is ON and OPEN indicating light is OFF.

Deleted Een or

Turn and hold selector switch for HV-P1 in OPEN position.

As Valve HV-Pl travels toward the open position, verify both OPEN and CLOSED indicating lights are ON.

When valve position handle on Valve HV-Pl shows fully open, verify OPEN indicating light is ON and CLOSED indicating light is OFF.

Release selector switch for HV-305 to AUTO. ECN-65

Release selector switch for HV-Pl to AUTO position.

Turn selector switch for HV-305 to OPEN position.

Verify Valve HV-305 starts to OPEN.

Verify HV-Pl begins to CLOSE as soon as HV-305 is fully OPEN.

Turn and hold selector switch for HV-305 in CLOSE positjon until $\mathrm{HV}-305$ is CLOSED and Step 10.2.37 is complete. Ecw 65

Turn and hold selector switch for HV-PI in OPEN position until HV-P1 is OPEN.

Release selector switch for HV-305 to AUTO. FCN $65^{-}$

Release selector switch for HV-PI to AUTO.

Depress DENY switch to Push to Deny position on Panel A in 242-S Control Room.

Verify PERMITTED indicating light on Panel IP3 is OFF.

Verify TRANSFER PUMP $P-1$ indicating Tight on Panel $A$ in 242-S is OFF.

Pull DENY switch to Pull to Reset position on Panel A in 242-S.

Verify HV-Pl begins to CLOSE. ECW 55

Verify $H V-305$ begins to OPEN. ECW 65

Using VOM verify Relay K-P on Panel IP2 is ENERGIZED.

Verify HV-305 position handle at top of valve actuator is in OPEN position.

$$
\begin{gathered}
\text { END OF SECTIONIO } \\
-\mathrm{Zl}_{1}-
\end{gathered}
$$


This test will demonstrate overall system operation by verifying the various interlocks perform the design functions. During this test no liquid will be pumped out of the tanks. Pump vendor assures that the pump can be run "DRY" for certain time duration.

\subsection{PREPARATION}

CY10+4.46

11.1.1 Verify a11 prerequisites of Para 7.1 and 7.2 have been met.

Notify 219-S, 222-S, 242-S, and 244-S Building Managers. Shiftmonagrs.

C5 $10 \cdot 14 \cdot 46$

11.1 .3

Notify Tank Farm Operations and Shift Manager.

Ch $10.14-46$

11.1.4 Verify that energized electrical work permits have been obtained.

NOTE: Keep appropriate personnel informed as to test status.

Ch10-14.96

11.1 .5

Verify all previous ATP sections have been completed satisfactority.

11.2 SYSTEM TEST

Ch10 $14-4$ G11.2.1 Verify Panel IP2 is ENERGIZED.

Chro-en-96 11.2 .2 Verify Pane] IP3 is ENERGIZEO.

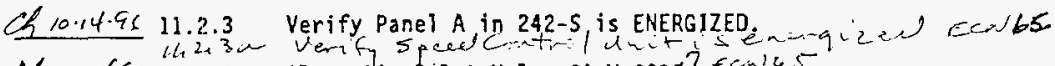

Ch10.4fal 11.2 .4 Close Air frilet Vaive CA-V-650D?

Ch10-14.9C 11.2.5 Verify DENY switch in Panel A at 242-S is in Pull to Reset position.

Chrout-GS 11.2 .6 Press and release PERMIT pushbutton in Panel A at 242-S.

CLo.14 Es 11.2.7 Verify TRANSFER PUMP P-1 indicating light at Panel A 242-S is ON.

Ch10.14-4y 11.2 .8 Verify PERMITTED indicating light on Panel IP3 is ON.

Ch10-14-4C 11.2 .9 Verify Siphon Valve KV-305 is OPEN.

Chw -14.2.10 Verify leak detection-indicating light-on Panel IP2 is OFF.

Ch covf-Gl 11.2.12 Verify pump diaphragm leak indicating light on Panel IP3 is ofF.

Cho-14 Ge 11.2.13 Verify Pump PI (air inlet) hand switch on Panel IP3 is in CLOSE position.

Chro-chas 11.2.14 Turn HV-P1 hand switch to OPEN and hold it momentariiy in that position.

Chio-149\}11.2.15 Verify HV-Pl begins to OPEN as indicated by both RED and GREEN indicating lights $O N$. 
Cf $10.44-46$ 11.2.15

Verify HV-P1 begins to OPEN as indicated by both RED and GREEN indicating lights $\mathrm{ON}$.

ahfolit/se 11.2 .16

Release HV-P1 hand switch allowing it to return to AUTO.

dy volutes 11.2 .17 Verify HV -PI begins to Close.

CX ofrelos 11.2.17a open air valve CA-V-660? car

Cholid/s, 11.2.19 Deleted

A $10 / 4 / 95$ 11.2.20 Verify HV-305 is CLOSE as indicated by indicating light.

Giolratac 11.2.21 Deleted

CA rolratsc 11.2.22 Turn and hold HV-PI hand switch on Panel IP3 to OPEN.

Goliflas 11.2 .23 Deleted

Choldeflab 11.2.23a

Release selector switch for $H V-305$ to AUTO. ECOU 5

Che fils 11.2.24 Release HV-P1 hand switch to AUTO. ELN'L5

Chide fe 11.2.24a Open Air Valve CA-V-6607.ecnls

Ch 101.4 91 11.2.24b Rotate speed control knob until it reads approximately 10 sig on pressure gauge.

Ch 10/14 96 11.2.25. Verify Pump P1 continues to run as indicated by indicating OPEN Tight.

Chidrflat 11.2.26 Lift wire marked LD-306A-4 at terminal 7 at panel IP2. ECNGS-

dhro/Mifat 11.2 .27 Verify valve HV-P1 starts to CLOSE. SCNUS

Grolufige 11.2 .28 Verify siphon Valve HV-305 starts to OPEN. Eesscr

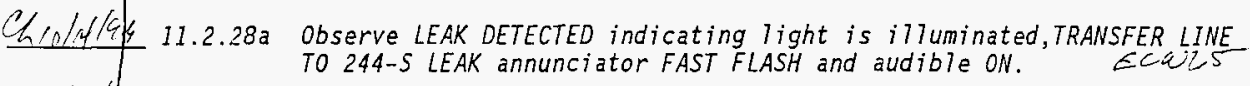

Chio/rute 11.2.286 Acknowledge annunciator. ECNL5

QLiolffs 11.2 .29 Reconnect wire at terminal 7 at panel IP2. ECNLS

C4 poly 191.2 .30 Verify Pump P1 remains STOPPED.

q cOy y 11.2 .31 Turn and Hold selector switch for HV-305 to CLOSE. ECW CS

C) $14\left(a_{6}\right.$ 11.2.32 Turn and Hold selector switch for HV-P1 to OPEN. ECWES

iffolith ic 11.2 .33 Verify Pump PI STARTS.

1210/4l \&4 11.2.33a Release selector switch for HV-305 to AUTO. ECWG

Chro-rual6 11.2.34 Release selector switch for HV -PI to AUTO. ECWGS

$-23-$

WHC-SD-W087-ATR-001

Rev. 0

$12 / 04 / 96$ 
Chro-ress 11.2.35 Verify Pump PI continues to run as indicated by OPEN light. Ch10.4.4 11.2.36 Depress DENY switch to Push to Deny position at 242-S Panel A. Ch114-GE 11.2 .36 a Verify HV-P1 starts to CLOSE. GeN 45

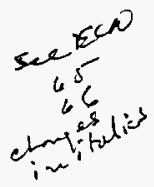
Chrowers 11.2.37 Verify Pump PI cannot START when Pump P1 hand switch is turned to
OPEN. Chrorreq 11.2.38 Verify Siphon valve is OPEN as indicated by indicating light oN. $0 / 40.14 .6$ 1 1].2.39 Pull DENY switch to Pull to Reset position. Ch10-44-96 11:2.40 Deleted Eenlar O4/0.14GC 11.2 .41 Press and release PERMIT pushbutton at 242-S Panel A. 
Ch 10-14.4S 11.2.42 Verify TRANSFER PUMP $P-1$ indicating light is ON at 242-S Panel A.

Ch10-rq-4\} 11.2.43 Verify PERMITTED indicating light on Panel IP3 is ON.

Ch10.49.66 11.2.43a Turn and hold selector switch for HV-305 in the close position.ECN 65

Ch10-ry-SC 11.2.43b Verify that HV-305 is CLOSED. Een wo

chio.14-46 11.2.43c Turn and hold selector switch for HV-P1 in the OPEN position. 566

Ch10\%4at 11.2 .44 Verify pump PI starts.

Ch10 1495 11.2.44a, Release selector switch for HV-305. ECLS

Ch10.14. ${ }_{6} 11.2 .44 b$ Release selector switch HV-P1. ECNS O410-r4-Y1 11.2.45 Simulate a leak in the Pl diaphragm at LDY-P1 by disconnecting power
at TBI-8HI.

CL16-14-4, 11.2.45a Verify DIAPH LEAK indicating light at IP3 is illuminated. ECNCS

G10-14.q1 11.2.45b Verify TANK 102 PUMP PI DIAPH LEAK annunciator window FAST FLASH and audible ON. ECNLS

Chio-tf-Gs 11.2.45c Acknowledge annunciator. Verify annunciator window STEADY ON and

Ch/ $0 \cdot 14 \cdot 9611.2 .46$ Verify Pump P1 air inlet valve starts to CLOSE.

Ch10.14 EC 11.2.47 Verify valve HV-305 opens.

Ch10rut-9S 11.2.48 Return LDY-PI to the Normal Mode by reconnecting power at TB1-8HI.

Ch10.refC 11.2.48a Verify DIAPH LEAK indicating light is not illuminated. Ecw 65

Chio-if ac 11.2.48b $\begin{aligned} & \text { Verify TANK } 102 \text { PUMP P1 DIAPH LEAK annunciator window SLOW FLASH and } \\ & \text { audible ON. }\end{aligned}$
ECW 5 .

Ch1074.af 11.2.48c Reset annunciator. Ecess

Cheortas 11.2 .49 Close air valve CA-V-660\%.

Chro-id-se 11.2.50 Return system to normal and safe configuration. ECNC6

END OF SECTION 11 